\title{
Management alternatives for Tetranychus urticae Koch (Acari: Tetranychidae) in the Carica papaya L. Hybrid Tainung-1
}

\section{Alternativas de manejo de Tetranychus urticae Koch (Acari: Tetranychidae) en Carica papaya L. Híbrido Tainung-1}
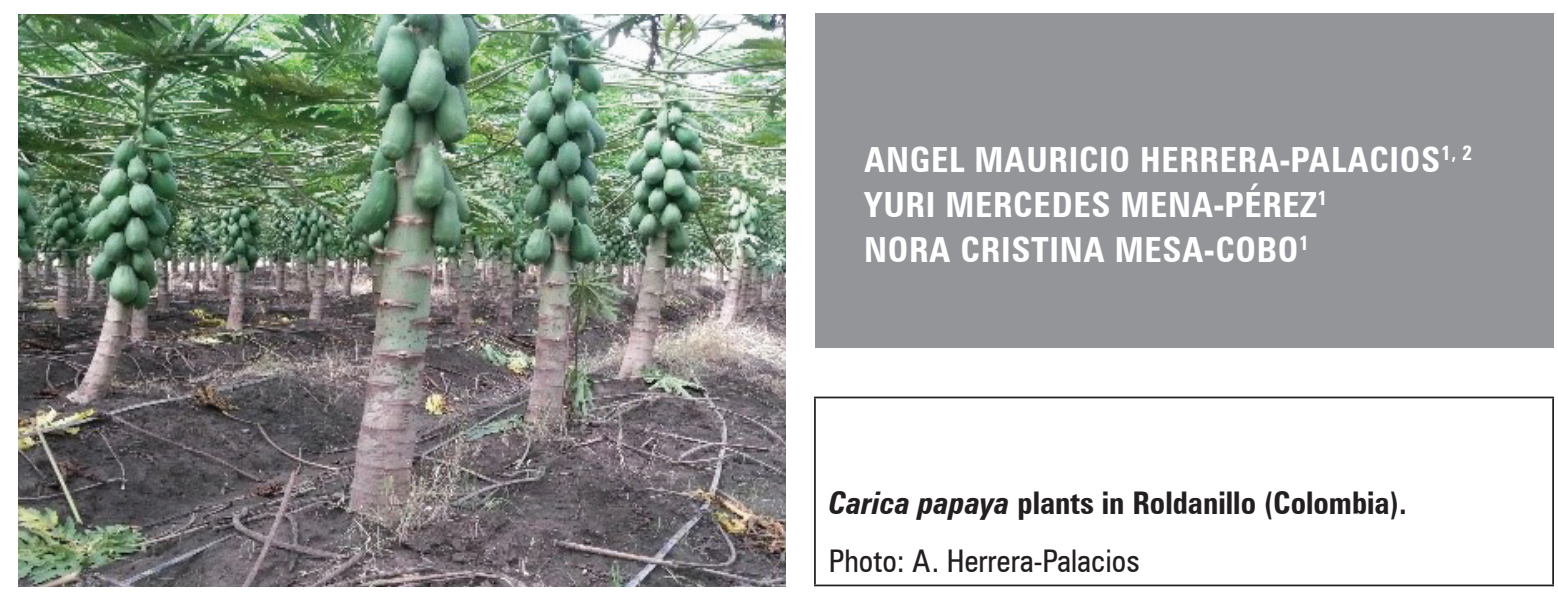

\section{ABSTRACT}

The mite Tetranychus urticae is a key pest in papaya crop in Valle del Cauca (Colombia), and it has been generally controlled with chemical products; other management alternatives have not been used. Therefore, this study aimed to evaluate the effects of alternatives: plant extract (garlic-chili vegetable extract, Alisin ${ }^{\circledR}$ ), mineral oil (vegetable fatty acid complex, Adimel®), entomopathogenic fungus (Successor ${ }^{\circledR}$ ), chemical control (spiromesifen, abamectin, fenazaquin), untreated (control treatment) and farmer's practices (14 applications of pesticides) in a randomized complete block design with three replications/treatment in a Hybrid Tainung- 1 papaya crop in the municipality of Roldanillo. The sampling was done every 8 days by measuring the variables: number of leaves/plant, number of infested leaves/plant, number of floral structures/plant, number of fruits/plant, diameter of stem/plant (every 30 days), population of T. urticae/leaf and yield. It was found that the populations of T. urticae/leaf were low in entomopathogenic fungus (11.978) and chemical control (10.548), with no significant differences $(P>0.05)$ from farmer's practices (3.339). In contrast, the mite populations were very high in plant extract (22.086), mineral oil (20.411) and untreated (35.746), as compared to farmer's practices. There was a significant difference in all treatments for the variable infestation from farmer's practices, and the number of leaves/plant in mineral oil and untreated treatment was significantly different from farmer's practices. No significant differences were found between the treatments in the rest of the evaluated variables. The entomopathogenic fungus turned out to be the best alternative for a management program of T. urticae in papaya in this region.

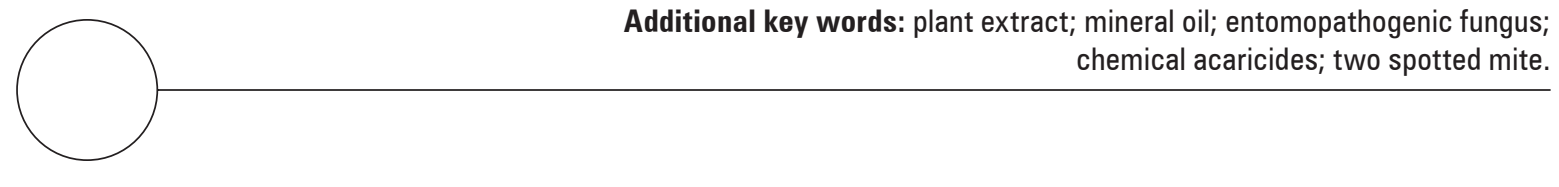

1 Universidad Nacional de Colombia, Faculty of Agricultural Sciences, Acarology and Entomology Group, Palmira (Colombia). ORCID Herrera-Palacios, A.M.: 0000-0003-4251-650X; ORCID Mena-Pérez, Y.M.: 0000-0001-5710-9742; ORCID Mesa-Cobo, N.C.: 0000-0003-4684-0219

2 Corresponding author. anmherrerapa@unal.edu.co 


\section{RESUMEN}

El ácaro Tetranychus urticae es considerada una plaga clave en el cultivo de papaya del Valle del Cauca (Colombia) y su control ha sido generalmente con productos químicos sin probar otras alternativas de manejo. Por lo anterior, el objetivo de este estudio fue evaluar en un cultivo de papaya Hibrido Tainung-1, en el municipio de Roldanillo, el efecto de las alternativas: extracto de planta (extracto vegetal de ajo-chile, Alisin $\left.{ }^{\circledR}\right)$, aceite mineral (complejo de ácidos grasos vegetales, Adimel®), hongo entomopatógeno (Successor $\left.{ }^{\circledR}\right)$, control químico (spiromesifen, abamectina, fenazaquin), sin manejo (tratamiento control) y prácticas del agricultor (14 aplicaciones de plaguicidas), utilizando un diseño de bloques al azar con tres repeticiones/tratamiento. Se hicieron muestreos cada 8 días midiendo las variables número de hojas/planta, número de hojas infestadas/planta, número de estructuras florales/planta, número de frutos/planta, diámetro del tallo/planta (cada 30 días), población de T. urticae/hoja y rendimiento. Se encontró que las poblaciones de T. urticae/hoja fueron bajas en los tratamientos hongo entomopatógeno $(11,978)$ y control químico $(10,548)$, donde no presentaron diferencias significativas $(P>0,05)$ con respecto a las prácticas del agricultor $(3,339)$; en contraste, las poblaciones del ácaro fueron muy elevadas en los tratamientos extracto de planta $(22,086)$, aceite mineral $(20,411)$ y sin manejo $(35,746)$ con respecto a las prácticas del agricultor. Se presentó una diferencia significativa en todos los tratamientos y prácticas del agricultor para la variable infestación y entre los tratamientos aceite mineral y sin control vs. prácticas del agricultor para número de hojas/planta. Del resto de variables evaluadas no se encontró diferencias significativas entre tratamientos. El hongo entomopatógeno resultó ser la mejor alternativa para un programa de manejo de T. urticae en papaya en el departamento.

Palabras clave adicionales: extracto vegetal; aceite mineral; hongo entomopatógeno; acaricidas químicos; ácaro de dos manchas.

Received for publication: 05-07-18 Accepted for publication: 30-11-2018

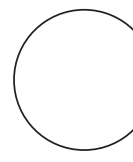

INTRODUCTION

The papaya (Carica papaya L.) is a high ranking fruit in terms of global production and, in Colombia, it ranks eighth for cultivated fruits since its fruit is highly desired by consumers, requiring high annual production to meet demand (Rios et al., 2005). There are limiting factors for its extensive production, such as diseases and pests, for example phytophagous mites, whose damage causes a decrease in optimal development and directly affects yield (Constantinides and Mchugh, 2003).

The species T. urticae is one of the pests that most affect the papaya, generating damage that consists of breaking and extraction of cell contents, causing chlorotic and tan spots (Badawy et al., 2010). This damage directly influences photosynthesis and increases the exposure of the fruit to the sun, with negative consequences for production and commercialization (Acuña et al., 2005). This pest is difficult to control and has a high reproduction rate (Ringuelet et al., 2012). In general, T. urticae is controlled with synthetic acaricides, with several applications during the production cycle, which increases costs and the emergence of resistance in this pest (Marques-Francovig et al., 2014).

The indiscriminate use of chemical products has generated serious problems related to water and soil contamination, directly affecting natural predators and pollinating insects that play a very important role in agriculture (Amaya et al., 2008; Gasca et al., 2011; Garcés, 2016). In addition, these products cause resistance and the appearance of secondary pests (Van Leeuwen et al., 2010; Encina et al., 2011). These drawbacks have created global concern and interest in the implementation of new pest control alternatives (Encina et al., 2011).

Alternative methods to chemical control have been increasing for several years, with the development of insecticides with a botanical origin, as well as the use of oils, entomopathogenic fungi and other products, in order to prevent or control T. urticae (Laborda et al., 2014; Grijalva and Tapia, 2015), reducing the impact of synthetic products on the environment and beneficial organisms found on farms (Akhtar et al., 2003). 
These alternative products present a complex mixture of substances whose mechanism of action is still unknown (IRAC, 2009), but which exert a wide range of physiological and behavioral effects on T. urticae (Padín et al., 2007; Afify et al., 2012; Tello et al., 2014). This study aimed to evaluate the effects of alternative treatments under field conditions: (plant extract, mineral oil, entomopathogenic fungus), a chemical control treatment (spiromesifen, abamectin, fenazaquin), an untreated (control treatment) and farmer's practices on populations of the phytophagous mite $T$. urticae in a papaya crop.

\section{MATERIALS AND METHODS}

This experiment was conducted in the municipality of Roldanillo, "La Pola" farm (Latitude: 4.40835; Length: -76.1069499999), which is $910 \mathrm{~m}$ asl, at a temperature of $24^{\circ} \mathrm{C}$ on average, with a relative humidity of $69 \%$ and $1,116 \mathrm{~mm}$ of annual precipitation. An experiment was established with 480 Tainung-1 hybrid papaya plants using a randomized complete block design with six treatments and three replicates of each. Each repetition consisted of 16 papaya plants.

The evaluated treatments were: (1) plant extract, garlic-chili vegetable extract (Alisin $\left({ }^{\circledR}\right)$; (2) mineral oil, vegetable fatty acid complex (Adimel®); (3) entomopathogenic fungus, Isaria fumosorosea (Successor $\left.{ }^{\circledR}\right)$; (4) chemical control, synthesis active ingredients (spiromesifen, abamectin and fenazaquin in rotation); (5) untreated (control treatment) and (6) farmer's practices, consisting of a $563 \mathrm{~m}^{2}$ commercial papaya crop ( $\operatorname{Tab} 1)$. At the edge of this crop, a plastic $5 \mathrm{~m}$ high barrier was placed to avoid infestation by T. urticae from one lot to another through the wind.

The applications started with the spontaneous appearance of T. urticae in the field, which was detected

\section{Table 1. Description of the treatments evaluated.}

\begin{tabular}{|c|c|c|c|c|c|}
\hline Treatment & Active ingredient & $\begin{array}{c}\text { IRAC } \\
\text { classification } \\
\end{array}$ & Action mode & Mechanism of action & $\begin{array}{l}\text { Doses } \\
\left(\text { L ha }^{-1}\right)\end{array}$ \\
\hline $\begin{array}{l}\text { Plant extract } \\
\qquad\left(\text { Alisin }^{\circledR}\right)\end{array}$ & $\begin{array}{l}\text { Allyl bisulphide } \\
\text { Limonene } \\
\text { Capsaicin } \\
\text { Nicotinic acid } \\
\text { Carotenoids }\end{array}$ & ---- & --------- & --------- & 600 \\
\hline $\begin{array}{l}\text { Mineral oil } \\
\left(\text { Adime }^{\circledR}\right)\end{array}$ & $\begin{array}{c}\text { Polialcohol } \\
\text { (zinc, manganese) }\end{array}$ & ---- & ------- & ------ & 600 \\
\hline $\begin{array}{l}\text { Entomopathogenic fungus } \\
\quad\left(\text { Successor }{ }^{\circledR}\right)\end{array}$ & $\begin{array}{l}\text { Isaria fumosorosea } \\
\text { Concentration: } 5 \times 10^{12} \\
\text { Conidium/L }\end{array}$ & ---- & By contact & ---------- & 600 \\
\hline \multirow{3}{*}{ Chemical control } & Spiromesifen & 23 & Systemic & Acetil CoA inhibitors carboxylase & 600 \\
\hline & Abamectin & 6 & By contact and ingestion & C1 channel activators & 600 \\
\hline & Fenazaquin & $21 \mathrm{~A}$ & By contact and ingestion & $\begin{array}{c}\text { Inhibitors of electron transport in } \\
\text { the mitochondrial complex }\end{array}$ & 600 \\
\hline $\begin{array}{c}\text { Untreated } \\
\text { (control treatment) }\end{array}$ & ----------- & & ------- & - - & ------- \\
\hline \multirow{5}{*}{$\begin{array}{c}\text { Farmer's practices } \\
\text { (Grower's practice of } \\
\text { commercial papaya crop) }\end{array}$} & $\begin{array}{l}\text { Spiromesifen } \\
\text { Abamectin }\end{array}$ & ---- & - & - & \multirow{5}{*}{1000} \\
\hline & Bifenazate & ---- & By contact & ------- & \\
\hline & Milbemectin & 6 & $\begin{array}{c}\text { By contact, ingestion } \\
\text { and translaminar activity }\end{array}$ & C1Channel activators & \\
\hline & Hexythiazox & $10 \mathrm{~A}$ & By contact and ingestion & Growth Inhibitors & \\
\hline & Acequinocyl & $20 \mathrm{~B}$ & By contact & $\begin{array}{l}\text { Inhibitors of electron transport in } \\
\text { the mitochondrial complex II }\end{array}$ & \\
\hline
\end{tabular}


with weekly monitoring of the populations. There were 9 applications in total of plant extract, mineral oil, entomopathogenic fungus and chemical control, at intervals of 21 days between applications starting at 40 days after the transplant (DAT) and ending with fruit filling (135 DAT), while, for farmer's practices, 14 applications were made.

Each repetition had 16 plants, 4 of which were marked. The number of total leaves infested with T. urticae, as evidenced by the presence of chlorotic spots, wilting and/or necrosis, were evaluated weekly in each of these plants. The number of floral structures (floral button, closed flower I, closed flower II and open flower) and number of fruits/plant from 60 DAT to half fruit filling (140 DAT) was also counted.

A leaf was taken weekly from the middle part of the plants in each treatment to the Entomology and Acarology laboratory of the Universidad Nacional de Colombia-Palmira Branch, where the number of individuals (egg, immature, adult) was counted for $T$. urticae. Tetranychidae and Phytoseiidae, with mounts using Hoyer medium were made for each sampling. All agricultural tasks of the crop, such as plant sexing, irrigation and fertilization, elimination of plants with viruses and control of other pests, diseases and weeds were carried out as established for the papaya crop.

\section{Statistic analysis}

The SAS statistical program SAS v. 9.3 (2014) for the analysis of variance (ANOVA) and Tukey means test at $5 \%(P \leq 0.05)$ significance were used to determine the significant statistical differences between the variables of the evaluated treatments. Fruits harvested per plant and total weight of fruits per treatment, the Fisher LSD test at $5 \%(P \leq 0.05)$ was performed.

\section{RESULTS}

\section{Fluctuation of $T$. urticae population dynamics}

In terms of the effect of treatments on the different stages of development of T. urticae, there was a significant difference between entomopathogenic fungus, chemical control and farmer's practices and plant extract, and untreated for the number of eggs per leaf, but there were no significant differences between mineral oil and entomopathogenic fungus, chemical control and untreated. The effect of entomopathogenic fungus was similar to the effect of farmer's practices, where the number of eggs per leaf was relatively low (Tab. 2).

Table 2. Average population of $T$. urticae per leaf for management alternatives in $C$. papaya crop.

\begin{tabular}{|l|c|c|c|}
\hline \multicolumn{1}{|c|}{ Treatment } & Eggs & Immatures & Adults \\
\hline Plant extract & $11.446 \mathrm{a}$ & $6.701 \mathrm{~b}$ & $3.939 \mathrm{~b}$ \\
\hline Mineral oil & $9.167 \mathrm{ba}$ & $7.431 \mathrm{~b}$ & $3.813 \mathrm{~b}$ \\
\hline $\begin{array}{l}\text { Entomopathogenic } \\
\text { fungus }\end{array}$ & $5.779 \mathrm{bc}$ & $4.282 \mathrm{bc}$ & $1.917 \mathrm{bc}$ \\
\hline Chemical control & $5.492 \mathrm{bc}$ & $3.458 \mathrm{bc}$ & $1.598 \mathrm{bc}$ \\
\hline Untreated & $12.280 \mathrm{a}$ & $15.080 \mathrm{a}$ & $8.386 \mathrm{a}$ \\
\hline Farmer's practices & $2.002 \mathrm{c}$ & $1.022 \mathrm{c}$ & $315 \mathrm{c}$ \\
\hline
\end{tabular}

Means with different letters in column indicate a significant differences according to Tukey's test $(P \leq 0.05)$.

The immature state (larvae and nymphs) and the adult state of $T$. urticae showed the same tendency in the population levels per leaf, where plant extract, mineral oil, entomopathogenic fungus, chemical control and farmer's practices had a significant difference from the untreated; however, plant extract and mineral oil were significantly different from the farmer's practices, unlike entomopathogenic fungus and chemical control, which presented a number of immatures and adults per leaf, similar to farmer's practices, with no significant differences in their populations (Tab. 2).

Farmer's practices showed the lowest populations of immature and adult $T$. urticae eggs present throughout the papaya vegetative cycle (Fig. 1-F); entomopathogenic fungus and chemical control showed a low population of T. urticae (no significant difference), as compared to those found in farmer's practices (Fig. 1-C, D). In contrast, plant extract and mineral oil had a higher number of similar (non-significant) pest individuals than untreated (Fig. 1-A, B, E). In all treatments, an explosion in the T. urticae population occurred from 60 DAT, decreasing at 88 DAT, corresponding to the beginning of flowering and ending at the beginning of fruiting.

Entomopathogenic fungus (I. fumosorosea) and chemical control presented a delay in the increase of T. urticae populations, in which the pest individuals began to grow from 76 DAT, at half of the flowering. And decreased at 88 DAT (beginning of fruiting) (Fig. 1-C, D). 


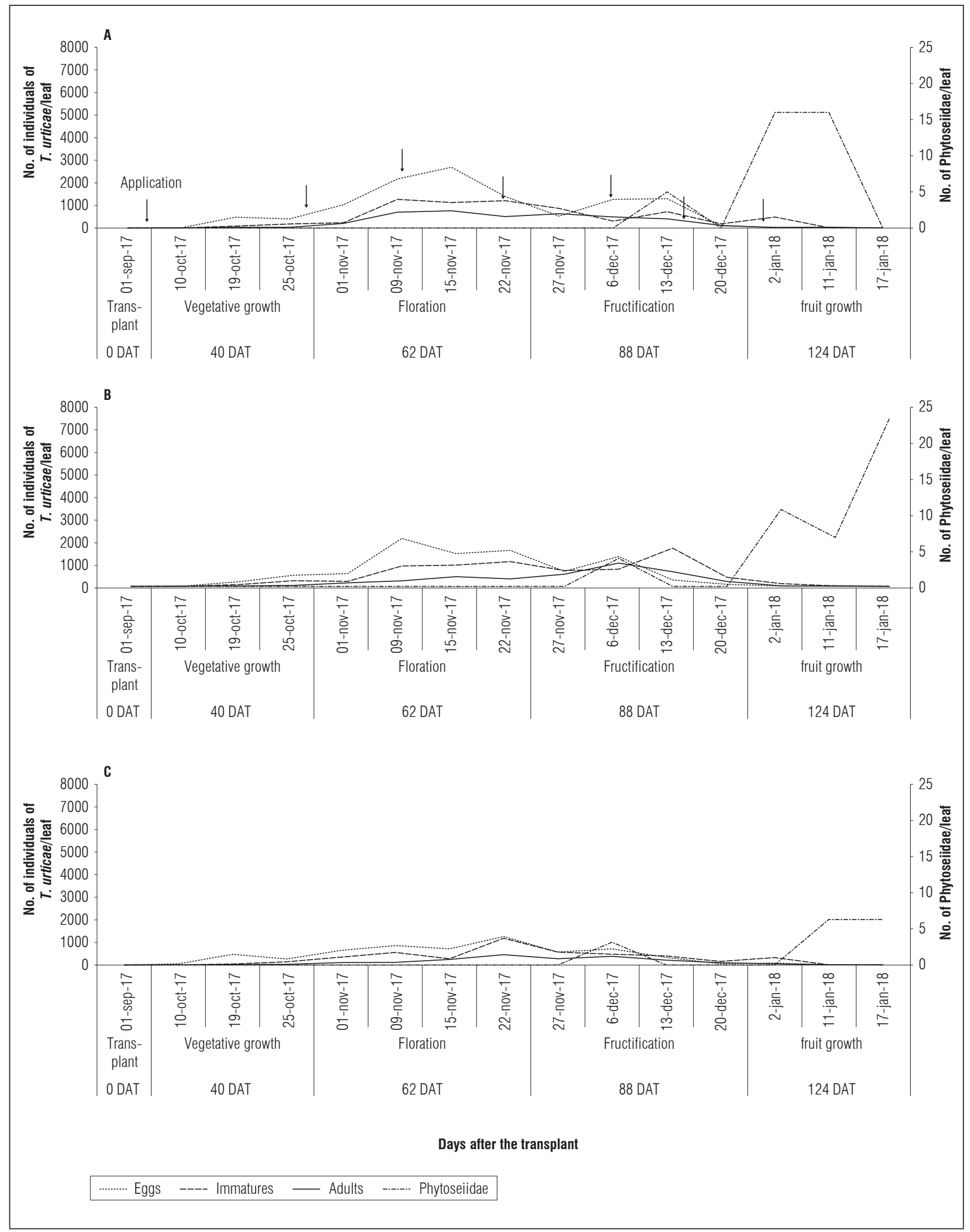

Figure 1. Population fluctuation of $T$. urticae with management alternatives in C. papaya crop. A, plant extract; B, mineral oil; C, entomopathogenic fungus. 


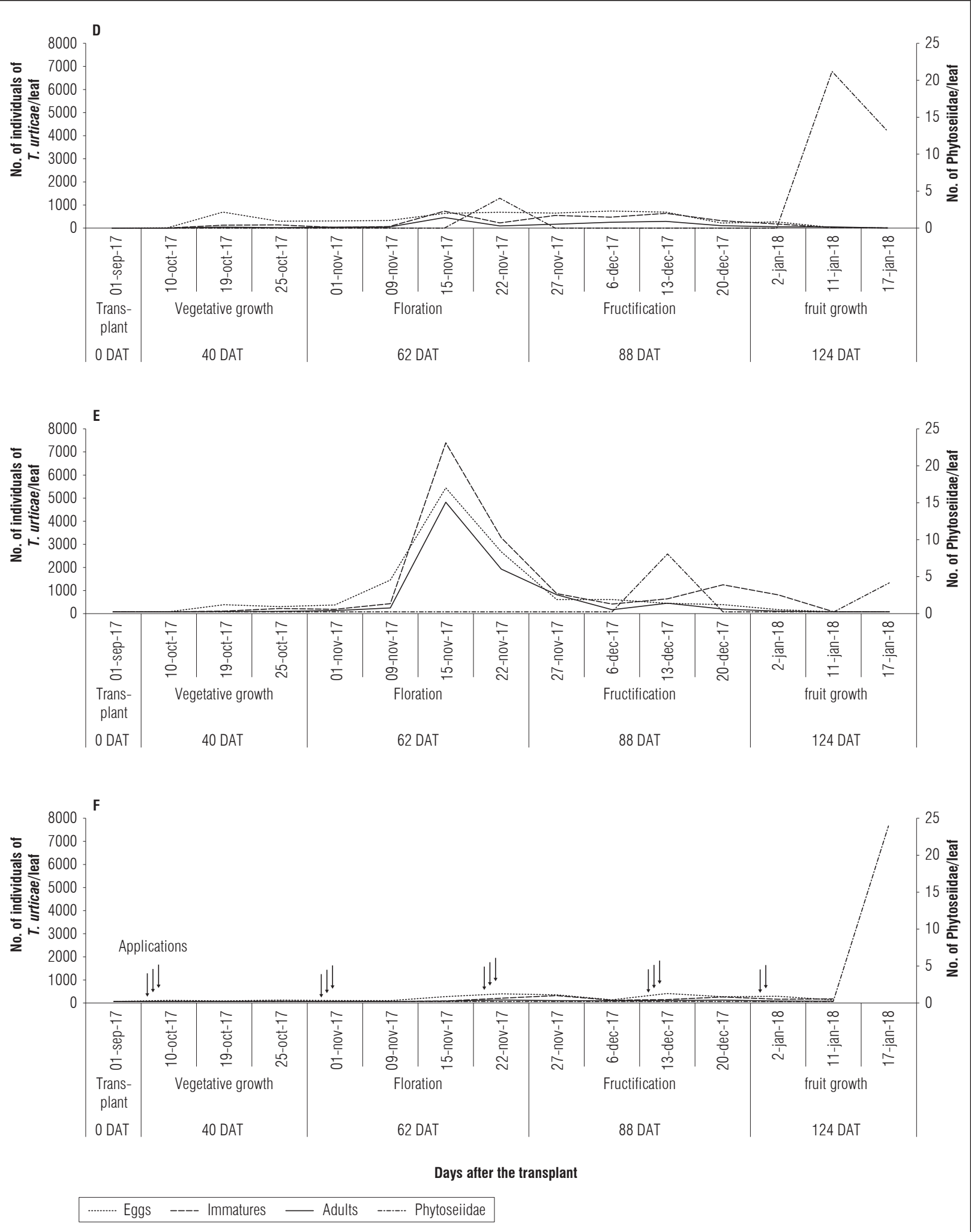

Continuation Figure 1. Population fluctuation of $T$. urticae with management alternatives in C. papaya crop. D, chemical control; $\mathrm{E}$, untreated treatment; $\mathrm{F}$, farmer's practices. 
The economic analysis of each control alternative for T. urticae, farmer's practices turned out to be the most expensive, where the cost of 14 applications/ ha was approximately \$COL 6,930,000 compared to the other treatments where the cost of seven applications/ha was much cheaper (plant extract \$COL $1,687,000$; mineral oil \$COL 1,568,000; entomopathogenic fungus $\$$ COL 2,170,000; chemical control \$COL 4,060,000 and untreated \$COL 0) (Tab. 3).

By identifying the assemblages of mites of the Phytoseiidae family, we found the species Euseius concordis (Chant) and Neoseiulus anonymus (Chant and Baker), whose species were present throughout the experiment in low quantities that did not exceed the 25 mites per papaya leaf in all the evaluated treatments. Entomopathogenic fungus and untreated treatment had the lowest number of Phytoseiidae per leaf of papaya (4 and 5 respectively) compared to mineral oil and farmer's practices where the number of Phytoseiidae per leaf was the highest (25), however, no significant differences were found between treatments for this variable. It is important to note that at the beginning of fruit filling the number of predatory mites increased in all treatments exerting a natural control of T. urticae populations in papaya plants (Fig. 1-A, B, C, D, E, F).

\section{Yield of the Tainung-1 hybrid papaya}

There was an uneven fruit ripening between treatments that varied between 171-220 DAT. There were no significant differences in the number of fruits per plant (Tab. 3), however, the number of fruits harvested per plant varied statistically in mineral oil, entomopathogenic fungus, chemical control and farmer's practices with 13,14, 16 and 14 fruits harvested per plant respectively, compared to untreated treatment where nine fruits were harvested per plant; in plant extract 12 fruits were harvested per plant, but did not show significant differences with untreated treatment. Significant differences were found in crop yield, where entomopathogenic fungus, chemical control and farmer's practices presented significant differences with respect to untreated treatment, obtaining the highest total fruit weights (25.1, 26.6 and $22.2 \mathrm{~kg}$, respectively). Plant extract and mineral oil were statistically equal to untreated treatment for this variable (Tab. 3).

\section{Agronomic variables}

Farmer's practices presented the highest number of leaves per plant (25), followed by plant extract, entomopathogenic fungus and chemical control, which presented 23, 24 and 24 leaves per plant, respectively. Mineral oil and untreated showed the lowest number of leaves per plant (22). The total number of leaves of each papaya plant did not show significant differences between plant extract, entomopathogenic fungus and chemical control and farmer's practices, except for mineral oil and untreated, which showed significant differences from farmer's practices (Fig. 2). The different evaluated treatments did not present significant differences for the infestation variable, except farmer's practices, which had significant differences from plant extract, mineral oil, entomopathogenic fungus, chemical control and untreated for this variable. The percentage of infestation in plant extract, mineral oil, entomopathogenic fungus, chemical control and untreated was found to be $81-84 \%$, while farmer's practices had a $64 \%$ infestation (Fig. 3).

Table 3. Papaya hybrid Tainung-1 yield per treatment.

\begin{tabular}{|l|c|c|c|c|}
\hline \multicolumn{1}{|c|}{ Treatment } & $\begin{array}{c}\text { Number of fruits } \\
\text { per plant }\end{array}$ & $\begin{array}{c}\text { Number of } \\
\text { harvested fruits }\end{array}$ & $\begin{array}{c}\text { Total fruit weight }{ }^{2^{*}} \\
(\mathrm{~kg})\end{array}$ & $\begin{array}{c}\text { Applications cost } \\
\text { (\$/ha) }\end{array}$ \\
\hline Plant extract & $19 \pm 3.16 \mathrm{a}$ & $12 \pm 1.53 \mathrm{bc}$ & $18.7 \pm 3.16 \mathrm{bc}$ & $1,687,000$ \\
\hline Mineral oil & $19 \pm 3.22 \mathrm{a}$ & $13 \pm 1.71 \mathrm{ba}$ & $19.7 \pm 3.33 \mathrm{bc}$ & $1,568,000$ \\
\hline Entomopathogenic fungus & $22 \pm 3.66 \mathrm{a}$ & $14 \pm 1.81 \mathrm{ba}$ & $25.1 \pm 4.24 \mathrm{ba}$ & $2,170,000$ \\
\hline Chemical control & $22 \pm 3.71 \mathrm{a}$ & $16 \pm 2.03 \mathrm{a}$ & $26.6 \pm 4.50 \mathrm{a}$ & $4,060,000$ \\
\hline Untreated & $16 \pm 2.80 \mathrm{a}$ & $9 \pm 1.16 \mathrm{c}$ & $14.8 \pm 2.50 \mathrm{c}$ & 0 \\
\hline Farmer's practices & $20 \pm 3.33 \mathrm{a}$ & $14 \pm 1.84 \mathrm{ba}$ & $22.2 \pm 3.75 \mathrm{ba}$ & $6,930,000$ \\
\hline
\end{tabular}

${ }^{1}$ Tukey test $(P=0.05)$. Equal letters no they represent significant statistical differences. ${ }^{2}$ Fisher's $L S D$ test $(P=0.05)$. Equal letters no they represent significant statistical differences. * Yield at two months of harvest 


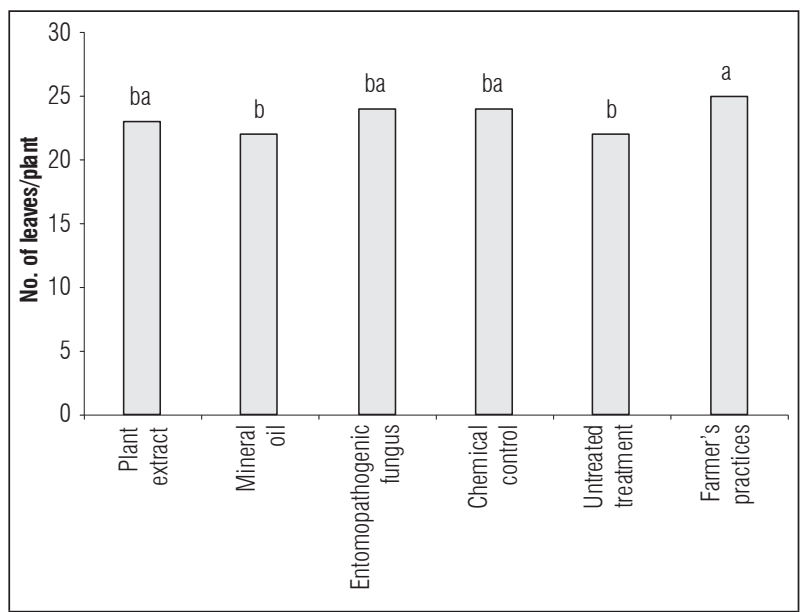

Figure 2. Number of leaves/plant in management alternatives for $\boldsymbol{T}$. urticae in the $\boldsymbol{C}$. papaya crop. Means with different letters indicate a significant differences according to Tukey's test $(P \leq 0.05)$.

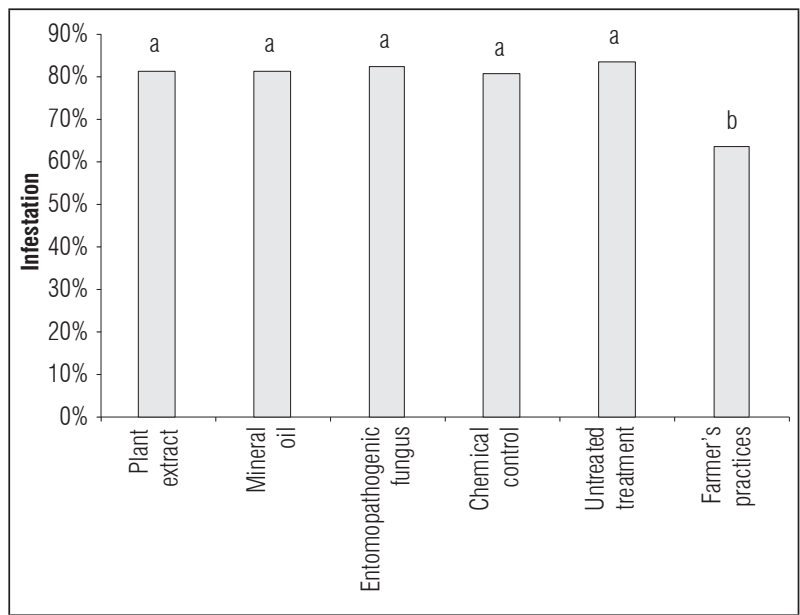

Figure 3. Percentage of infestation (leaves infested by plant) in management alternatives for $T$. urticae in the $C$. papaya crop. Means with different letters indicate a significant differences according to Tukey's test $(P \leq 0.05)$.

The variables stem diameter, number of floral structures (flower buds, closed flowers I, closed flowers II, and open flowers) and number of fruits per plant did not present significant differences in the evaluated treatments (Fig. 4 y 5 ).

There were high rainfall periods and high temperatures during the evaluation period of the study in the experimental lot that was 7.5 months (40-220 DAT) for the evaluated variables (number of leaves per plant, number of infested leaves per plant, number of floral structures per plant, number of fruits

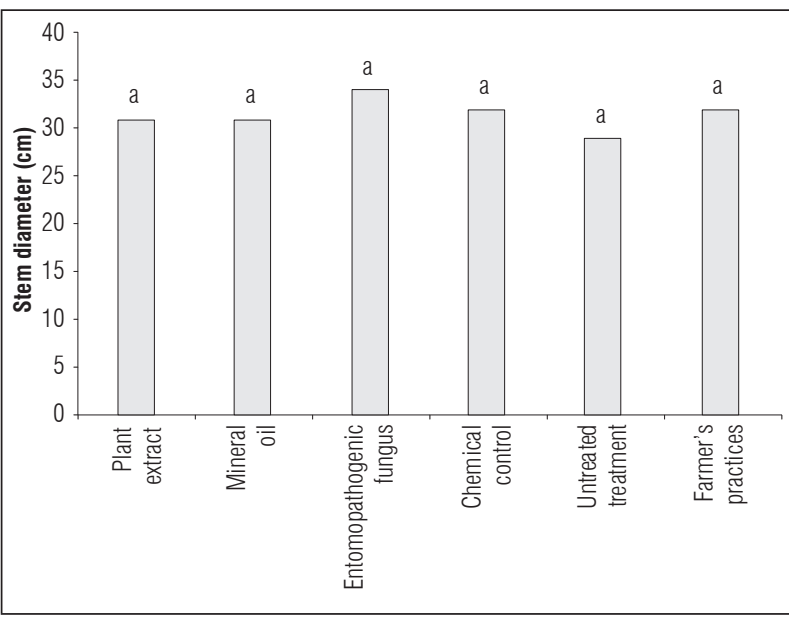

Figure 4. Diameter of stem/plant in management alternatives for $\boldsymbol{T}$. urticae in the $C$. papaya crop. Means with different letters indicate a significant differences according to Tukey test $(\boldsymbol{P} \leq \mathbf{0 . 0 5})$.

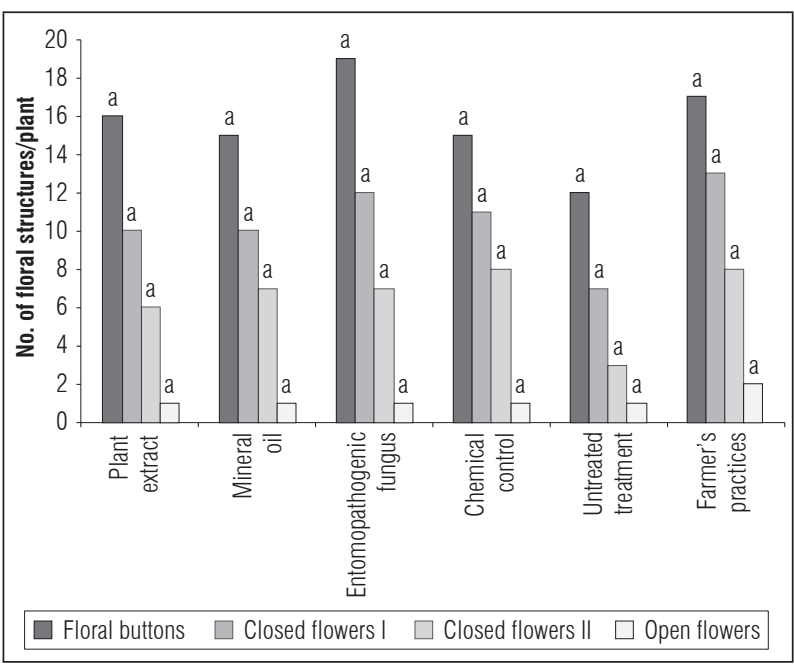

Figure 5. Number of floral structures/plant in management alternatives for $T$. urticae in the $C$. papaya crop. Means with different letters (between treatments) indicate a significant differences according to Tukey's test $(P \leq 0.05)$.

per plant, diameter of the stem and population of $T$. urticae per leaf) plus 60 days after the beginning of harvest (220-280 DAT) to evaluate yield; however, no negative effects were found between the populations of T. urticae in its three stages of development (egg, immature, adult) with climatic conditions precipitation (probability of correlation: -0.33865 ) and relative humidity (PC: -0.02133 ), but with the temperature (PC: 0.29949) (Fig. 6), whose averages were the following: temperature $23.1^{\circ} \mathrm{C}$, relative humidity $81.3 \%$ and a precipitation of $445.9 \mathrm{~mm}$. 

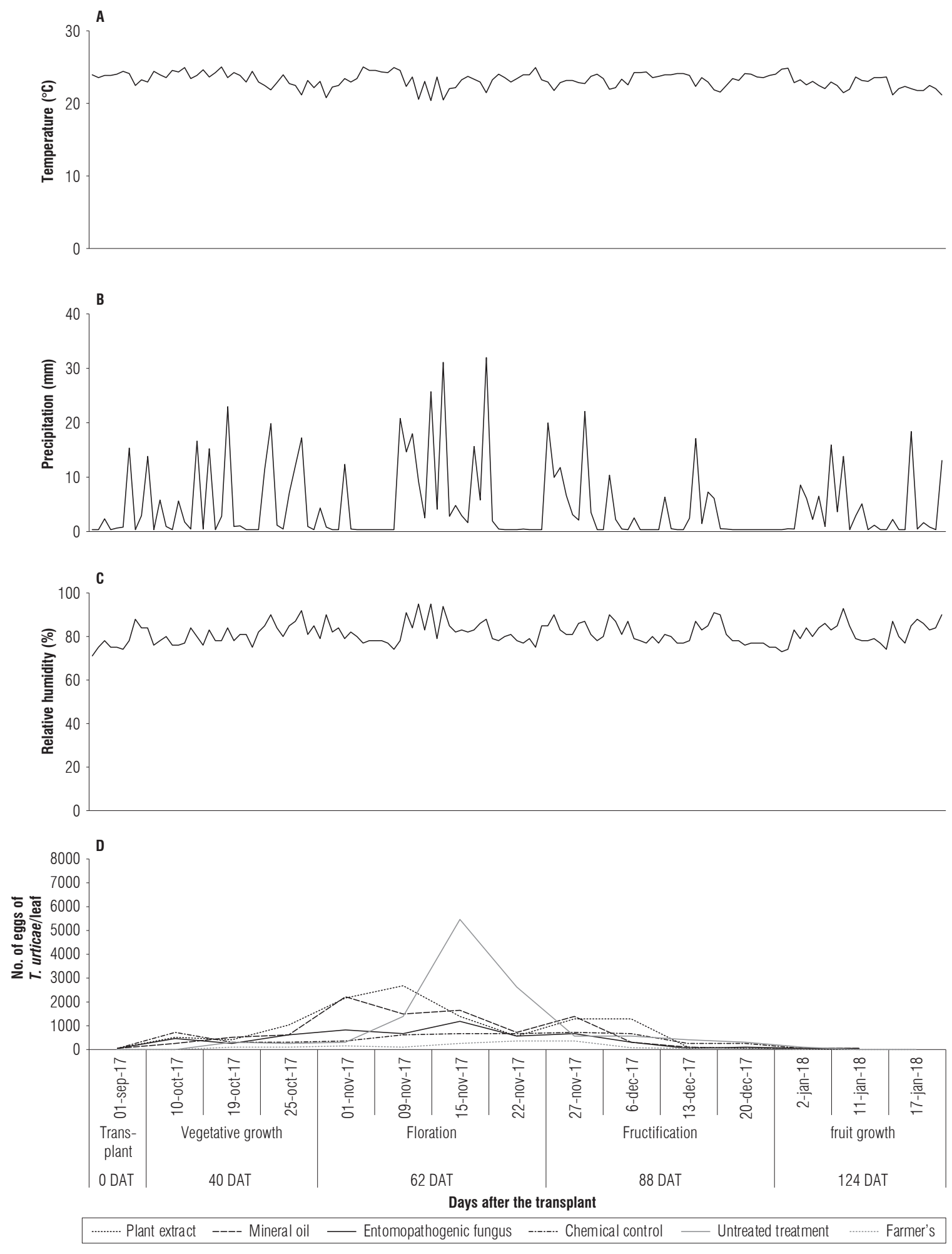

Figure 6. Average population of $T$. urticae per leaf and climatic conditions. 


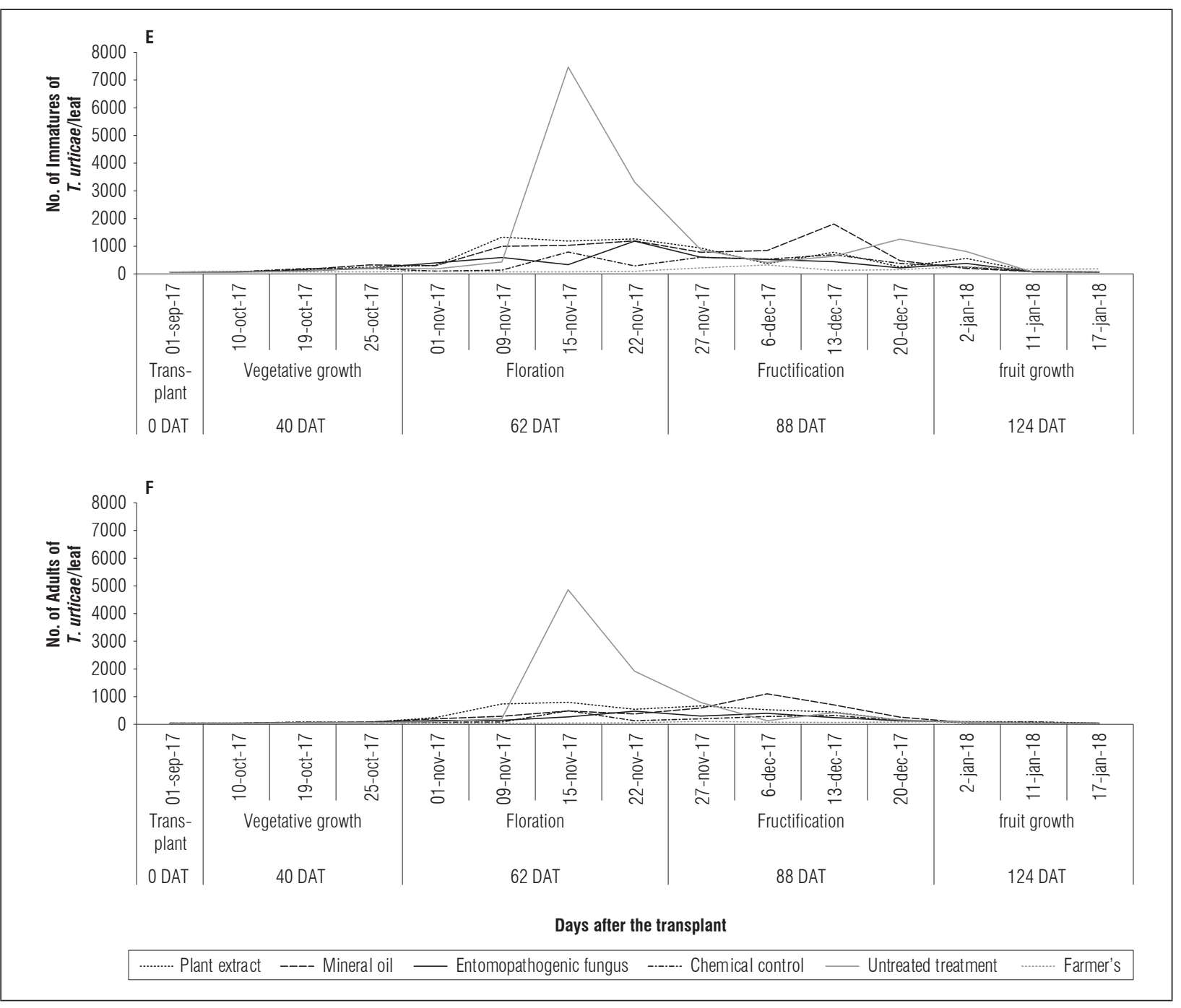

Continuation Figure 6. Average population of $T$. urticae per leaf and climatic conditions.

\section{DISCUSSION}

In the department of Valle del Cauca, Colombia, the species T. urticae has been reported as a key pest in papaya cultivation because it is difficult to control and has a high reproduction rate, resulting in high amounts of mites per leaf and per plant (Gómez et al., 2014; Mena et al., 2017); the results found in this study coincide with the findings of other authors since, in this study, populations of up to $35,746 \mathrm{~T}$. urticae individuals were seen per papaya leaf. The climatic conditions (temperature, precipitation, relative humidity) have generally been a determining factor in the populations of mites present in the crops; the temperature showed a positive correlation with the populations of T. urticae, however, in this study the precipitation and relative humidity showed a negative correlation with the number of pest mites per leaf (Fig. 6), this could be due to the position of the mite in the leaf, since when located in the lower part (underside), this could significantly reduce the direct action of rain (drop impact), which is supported by Abato-Zárate et al. (2018) in their study of the population dynamics of the Tetranychidae mites associated with $C$. papaya in Mexico, where the climatic conditions did not have any influence on the population amounts of the arachnids.

In this study, the treatment with the best results was farmer's practices, where 14 applications of synthetic acaricides were used. However, performing 9 applications of the entomopathogenic fungus 
(I. fumosorosea) and the chemical synthesis acaricides (spiromesifen, abamectin, fenazaquin) did not have a significant difference in the control of the three stages of development of T. urticae (egg, immature, adult) with respect to farmer's practices, which coincides with that found by (Shi and Feng, 2009) and (Sato, 2011), where the extracts used had a low percentage of T. urticae mortality, whereas the chemical synthesis products and the entomopathogenic fungus (I. fumosorosea) presented a positive control of this pest.

The results obtained in farmer's practices reflect the findings of Gómez et al. (2014) and Mena et al. (2017) for the chemical controls in the Department of Valle del Cauca, where $95 \%$ of the papaya producers use a large number of active ingredients of chemical synthesis to control T. urticae and the remaining 5\% use other management alternatives (extracts and oils extracted from plants, entomopathogenic fungi) to control this pest.

While it is true that farmer's practices showed the lowest levels of individuals of T. urticae per leaf, the cost of 14 applications increased (\$COL 6,930,000/ha) compared to entomopathogenic fungusthat showed no significant differences with farmer's practices and the cost of seven applications turned out to be is less expensive (\$COL 2,170,000/ha) (Tab. 3), results that match those found by (Rodríguez, 2012) in "valencia" orange, where the use of entomopathogenic fungus controlled the statistics of white mite (Polyphagotarsonemus latus Banks) and the cost in applications/ha been much cheaper than chemical control. Hence the importance of this control alternative to be incorporated into an integrated management system of $T$. urticae that minimizes the costs of control, the impact on the environment and wildlife benefits and in the same way, satisfactory yields are obtained.

The untreated treatment had significant differences for the number of leaves per plant from the farmer's practices and, in view of the fact that leaves are responsible for synthesizing the carbohydrates that will be distributed to the different organs of the plant, it is evident that a decrease in crop will be seen when $T$. urticae mites cause leaf necrosis and defoliation (Constantinides and Mchugh, 2003); this coincides with that found in this study, where entomopathogenic fungus (I. fumosorosea) had a significant difference in yield from untreated, results that are similar to those found by Park and Lee (2005) in cucumber and by Mena et al. (2017) in the papaya hybrid Tainung-1, where T. urticae mites directly affected the yield of these crops.

All evaluated treatments presented a significant difference for the infestation variable with respect to farmer's practices, results also found by AbatoZárate et al. (2012) in the papaya "Maradol" variety, where a significant difference between treatments was observed for the variable number of mite pests per leaf. Regardless of the control alternative used on T. urticae, the variables stem diameter, number of floral structures per plant and number of fruits per plant were not compromised. These results are similar to those found by (Landeros et al., 2009) and (Lema, 2013) in roses, where no significant differences were found in stem thickness or number of floral structures in plants infested with T. urticae.

\section{CONCLUSIONS}

Entomopathogenic fungus (I. fumosorosea) significantly reduced $T$. urticae populations and had no significant differences from farmer's practices and chemical control.

Entomopathogenic fungus showed no significant differences in yield from farmer's practices.

The yield in untreated was reduced by about $45 \%$ in relation to entomopathogenic fungus, chemical control and farmer's practices.

Plant extract (garlic-chili extract) and mineral oil (complex of fatty acids) did not reduce populations of T. urticae, and the yields did not have significant differences from untreated.

The results obtained in this study suggest that this experiment should be replicated in more cycles of papaya production in order to obtain more precise results that would contribute to scientific strengthening of the management of this pest (T. urticae) with the aforementioned control alternatives; in addition, the effects of other extracts and oils of a botanical origin different from those used in the present investigation should be evaluated in order to obtain satisfactory results in the management of this pest mite in papaya cultivation.

Conflict of interests: this manuscript was prepared and reviewed with the participation of the authors, who declare that there exists no conflict of interest that puts at risk the validity of the presented results. 


\section{BIBLIOGRAPHIC REFERENCES}

Abato Z., M., J. Villanueva J., G. Otero C., C. Ávila R., and N. Reyes P. 2018. Dinámica poblacional de ácaros de las familias Tetranychidae y Phytoseiidae asociados al papayo (Carica papaya). Acta Zool. Mex., 34(1). Doi: 10.21829/azm.2018.3411180

Abato-Zárate, M., J.A. Villanueva-Jiménez, G. Otero-Colina, C. Ávila-Reséndiz., E. Hernández-Castro, and N. Reyes-Pérez. 2012. Biological efficacy and selectivity of acaricides in papaya (Carica papaya L.). Trop. Subtrop. Agroecosyst. 15(Suppl. 2), 118-125.

Acuña, L.E., J.P. Agostini, and T.H. Haberle. 2005. Control químico del ácaro blanco Polyphagotarsonemus latus Banks. del mamón Carica papaya L. Citrusmisiones 30, 10-20.

Afify, A.E.-M.M.R., F.S. Ali, and A.F. Turky. 2012. Control of Tetranychus urticae Koch by extracts of three essential oils of chamomile, marjoram and Eucalyptus. Asian Pac. J. Trop. Biomed. 2(1), 24-30. Doi: 10.1016/ S2221-1691(11)60184-6

Akhtar, Y., C.H. Rankin, and M.B. Isman. 2003. Decreased response to feeding deterrents following prolonged exposure in the larvae of a generalist herbivore, Trichoplusia ni (Lepidoptera: Noctuidae). J. Insect Behav. 16(6), 811-831. Doi: 10.1023/B:JOIR.0000018322.45068.a9

Amaya V., D., A. Barrera, A. Hilarión G., A. Bustos R., and F. Cantor R., 2008. Evaluación de la efectividad de dos hongos entomopatogenos y un extracto vegetal, para el control de Tetranychus urticae, en condiciones de laboratorio. Rev. Fac. Cienc. Básicas 4(1-2), 62-69. Doi: $10.18359 / \mathrm{rfcb} .2232$

Badawy, M.E.I., S.A.A. El-Arami, and S.A.M. Abdelgaleil. 2010. Acaricidal and quantitative structure activity relationship of monoterpenes against the two-spotted spider mite, Tetranychus urticae. Exp. Appl. Acarol. 52(3), 261-274. Doi: 10.1007/s10493-010-9363-y

Constantinides, L.N. and J.J. Jr. Mchugh (eds.). 2003. Pest management strategic plan for banana production in Hawaii. Workshop Summary. University of Hawaii at Manoa, Honolulu, Hawaii.

Encina R., R.L., M.B. Ramírez de L., and C.D. Pino Q. 2011. Efecto de dos extractos acuosos de meliáceas sobre Tetranychus spp. (Acari: Tetranychidae) en condiciones de laboratorio. Investig. Agrar. 27(2), 195-199.

Garcés G., C. 2016. Estudio de la eficacia de productos ecológicos en el control de Tetranychus urticae en el cultivo de cítricos. $\mathrm{PhD}$ thesis. Universidad Politécnica de Valéncia, Valencia, Spaish.

Gasca C., V.M., R. Barrientos M., and C. Chi N. 2011. Los plaguicidas y su impacto sobre la fauna silvestre de la Península de Yucatán. Bioagrociencias 4(2), 4-9.

Gómez, E.D., N.C. Mesa, Y.M. Mena, L. Álvarez, C.A. Hernández, J.A. Salazar, K. Imbachi, O. Sánchez, H. Marulanda, M.L. Velasco, E.D. Henao, O.E. Sánchez, D.
Vásquez, P. Ramos, S. Benítez, E.Y. Sánchez, R. López, E.I. Estrada, R. Reina, Y. García, C.A. Huertas, I. Rodríguez, G.M. Cobo, Y. Peteche, J. Piza, S. Rodríguez, E.P. Barinas, C. Vega, L.A. Londoño, R. Romero, and P.E. Gamboa. 2014. Programa de manejo fitosanitario en papaya en el Valle del Cauca. Facultad de Ciencias Agropecuarias, Universidad Nacional de Colombia, Palmira, Colombia.

Grijalva S., P.T. and A.D. Tapia C. 2015. Evaluación de la actividad acaricida del aceite esencial de congona (Peperomia inaequalifolia). Undergraduate thesis. Universidad Politécnica Salesiana, Quito.

IRAC, Insecticide Resistance Action Committee. 2009. IRAC Susceptibility Test Methods Series, version 3 (June). In: https://www.irac-online.org/documents/ irac-test-methods-introduction-and-overview-v3/?ex$\mathrm{t}=$ pdf; consulted: May, 2018.

Laborda, R., I. Manzano., M. Gamón., I. Gavidia., P. Pérez-Bermúdez, and R. Boluda. 2014. Estudio de la actividad biocida de aceites procedentes de plantas aromáticas sobre Tetranychus urticae y Ceratitis capitata. Agric. Ganad. Ecol. 15, 28.

Landeros, J., R. Flores, E. Cerna, M. Badii, L. Guevara, and Y. Ochoa. 2009. Efecto de diferentes densidades de Tetranychus urticae Koch (Acari: Tetranychidae) en algunos parámetros de calidad de rosas bajo condiciones de invernadero. Folia Entomol. Mex. 48(1), 21-28.

Lema T., S.M. 2013. Control biológico de araña roja (Tetranychus urticae), en tres variedades de rosas (rosa sp.) de exportación a través de dos depredadores biológicos en la empresa Texas Flowers S.A. Undergraduate tesis. Universidad Técnica de Cotopaxi, Latacunga, Ecuador.

Marques-Francovig, C.R., A.Y. Mikami, V. Dutra, M.G. Carvalho, B. Picareli, and M.U. Ventura. 2014. Organic fertilization and botanical insecticides to control two-spotted spider mite in strawberry. Cienc. Rural 44(11), 1908-1914. Doi: 10.1590/0103-8478cr20131575

Mena, Y.M., N.C. Mesa, J. Salazar, L.M. Gonzales, and M.S. Pérez. 2017. Impacto causado por Tetranychus urticae (Acari: Tetranychidae) al cultivo de papaya (Carica papaya L.). In: Resúmenes XLIV Congreso Sociedad Colombiana de Entomología. Bogotá.

Padín, S.B., E.M. Ricci, C. Henning, S. Ré., J. Ringuelet, and E. Cerimele. 2007. Insecticidas botánicos para el control de Myzus persicae Sulz. (Hemíptera: Aphididae) en Brassica olaracea var. Capitata. Bol. San. Veg. Plagas 33(2), 187-185.

Park, Y.L. and J.H. Lee. 2005. Impact of twospotted spider mite (Acari: Tetranychidae) on growth and productivity of glasshouse cucumbers. J. Econ. Entomol. 98(2), 457-463. Doi: 10.1093/jee/98.2.457

Ringuelet, J.A., M.I. Urrutia., R.M. Yordaz, and C.P. Henning. 2012. Actividad insecticida y repelente de aceites esenciales de laurel y lemongrass sobre Bemisia tabaci. Bol. San. Veg. Plagas 31(1900), 353-360. 
Rios, M.M., C.J. Marquez, and H.J. Ciro. 2005. Deshidratacion osmotica de frutos de papaya hawaiiana (Cariaca papaya L.) en cuatro agentes edulcorantes. Rev. Fac. Nac. Agron. Medellín 58(2), 2989-3002.

Rodríguez T., I.V. 2012. Identificación de ácaros que afectan cultivos de naranja valencia (Citrus sinensis L.) en el núcleo sur occidental de Colombia y establecimiento de dinámica de población y fenología de algunas especies de importancia económica. PhD thesis. Universidad Nacional de Colombia, Palmira, Colombia.

Sato, M.E., M.Z. Da Silva, A. Raga, K.G. Cangani, B. Veronez, and R.L. Nicastro. 2011. Spiromesifen toxicity to the spider mite Tetranychus urticae and selectivity to the predator Neoseiulus californicus. Phytoparasitica 39(5), 437
Shi, W.B. and M.G. Feng. 2009. Effect of fungal infection on reproductive potential and survival time of Tetranychus urticae (Acari: Tetranychidae). Exp. Appl. Acarol. 48(3), 229-237. Doi: 10.1007/s10493-009-9238-2

Tello M., V., S.J. Chung, and R. Vargas M. 2014. Estudio preliminar del efecto acaricida de seis extractos metanólicos sobre la arañita bimaculada, Tetranychus urticae Koch. Idesia 32(2), 37-45. Doi: 10.4067/S0718-34292014000200006

Van Leeuwen, T., J. Vontas, A. Tsagkarakou, W. Dermauw, and L. Tirry. 2010. Acaricide resistance mechanisms in the two-spotted spider mite Tetranychus urticae and other important Acari: A review. Insect Biochem. Mol. Biol. 40(8), 563-572. Doi: 10.1016/j.ibmb.2010.05.008 